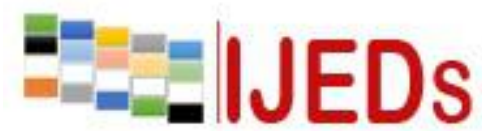

http://ijeds.ppj.unp.ac.id/index.php/IJEDS

\title{
IMPROVEMENT OF SCIENCE LEARNING OUTCOMES WITH PROBLEM BASED LEARNING METHOD: CLASS ACTION RESEARCH STUDY
}

\author{
${ }^{*}$ Desi ${ }^{1}$ and Yanti Fitria ${ }^{2}$ \\ ${ }^{1}$ Post Graduate Elementary Education Universitas Negeri Padang \\ ${ }^{2}$ Lecturer Elementary Education Universitas Negeri Padang \\ E-mail:deszyjee@gmail.com
}

*Corresponding Author, Received: November 12, 2018, Revised: December 10, 2018, Accepted: December 21, 2018

\begin{abstract}
This research was conducted due to fifth grade studen's low learning achievement at SD Negeri 10 Sapiran Bukittinggi. The aim of this research was to describe the improvement of the student's learning achievement in Natural Scince by using Problem Based Learning (PBL) strategy in the fifth grade of SD Negeri 10 Sapiran Bukittinggi. This was a classroom action researchwhich applied qualitative and quantitative approaches.the resultof the research indicated that thestudent'slearning achievement improved from 78,01in the first cycle into 93,22 in the second cycle. Hence, the use of PBL strategy could improve the students learning achievement in Natural Science in the fifth grade of SD Negeri 10 Sapiran Bukittinggi.
\end{abstract}

Keywords: Learning Outcomes, Science, Problem Based Learning (PBL) Strategy

\section{INTRODUCTION}

In this age of industry 4.0 people are asked to develop certain abilities. One of them is the ability to solve problems. Current learning does not train students to find their own answers and solve problems faced in learning (Chen \& Chen, 2008). It is very important for students to know and understand how to solve problems in order to increase their knowledge of values, especially the value of science science (Demirel \& Caymaz, 2015). One of the solutions to solving these problems is Problem Based Learning (Phungsuk et al, 2017). Real problems are the starting point of probem based learning. Students are asked to be able to think critically in solving problems found. (Gorghiu et al, 2015). Students learn to motivate themselves in solving each problem (Moutinho et al., 2015). Problem based learning also requires students to learn 


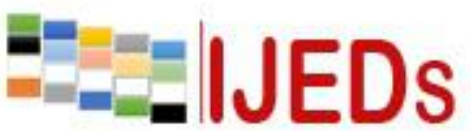

http://ijeds.ppj.unp.ac.id/index.php/IJEDS
International Journal of Educational Dynamics

Vol. 1 No. 1 (pp. 169-174) December 2018

p_ISSN 2655-4852

e_ISSN 2655-5093

independently to find effective ways to solve problems (Harun et al, 2012).

PBL starts from problems that will later have a lot of problem solving (Yusof et al, 2012). Polya presents a problem solving procedure that consists of 4 steps: understanding the problem, drawing up a plan, implementing the plan, and looking back (Polya, 1957) (Panlumlers and Wannapiroon, 2015). PBL is designed to help students solve problems with their abilities, including students' critical thinking skills (Mat et al 2012). Template based learning can be applied to learning in elementary schools, especially 4th grade science learning. Science learning requires the ability to find answers to problems (Demirel and Caymaz, 2015).

\section{METHOD}

This study uses a type of classroom action research (PTK) using qualitative and quantitative data analysis with research subjects of fifth grade students of Sapiran Bukittinggi 10 Elementary School in the second semester of the 2016/2017 Academic Year with 32 students. (Primary Data of Sapiran Public Elementary School 10 Bukittinggi, 2016). This research uses the flow of the Kemmis \& Mc Taggart research model, et al (Arikunto et al., 2009).

\section{RESULTS AND DISCUSSION}

\section{First Cycle I Meeting}

The results obtained are teacher activities, in learning the first cycle of meeting I with a percentage of $75.00 \%$ enough category. While student activities, the percentage is $78.33 \%$ with sufficient categories. Then the learning results obtained an illustration that from 32 students only 19 students were able to reach the standard of mastery learning and 13 students had not been able to reach the standard of mastery learning. The percentage of class average is $75.21 \%$.

From the learning outcomes obtained can be described: (1) Cognitive aspects, the success of students from cognitive aspects seen during the learning process takes place during the first cycle of meeting I with an average percentage of $72.71 \%$ with less categories (K); (2) Affective aspects, The success of students from the affective aspects of this meeting is $76.87 \%$ with sufficient categories (C); (3) Psychomotor aspects, The 


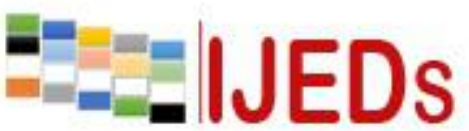

http://ijeds.ppj.unp.ac.id/index.php/IJEDS
International Journal of Educational Dynamics

Vol. 1 No. 1 (pp. 169-174) December 2018

p_ISSN 2655-4852

e ISSN 2655-5093

success of students from the psychomotor aspects at this meeting was $76.03 \%$ with sufficient categories (C).

\section{Second Cycle of Meeting II}

The results of observation of teacher activities, the number of scores with a percentage of $85.00 \%$ good category (B). While student activity, the score obtained was a percentage of $86.67 \%$ in the good category (B). Based on the results of the study obtained an overview of 32 students only 23 students were able to reach the standard of mastery learning and 9 students with the percentage of the average class obtained was $80.00 \%$. From the learning results obtained can be described: (1) cognitive aspects, the success of students from the cognitive aspects seen during the learning process takes place with an average percentage of $77,11 \%$ with a good category (B); (2) Affective aspects, The success of students from the affective aspects of this meeting is $81.24 \%$ with good categories (B); (3) Psychomotor aspects, the success of students from psychomotor aspects is $80.82 \%$ with good categories (B).

\section{Cycle II Meeting I}

The results of observations made on teacher actions, the number of scores obtained 54 from the maximum score of 60 with a percentage of $90.00 \%$ with a very good category (A). Whereas for student actions, the score obtained is 57 from a maximum score of 60 with a percentage of $95.00 \%$ with a very good category (A). Student learning outcomes are seen from the results of evaluations conducted at the end of learning. Based on the results of learning can be obtained an illustration that of 32 students 28 students were able to reach the standard of mastery learning, 4 students had not been able to reach the standard of mastery learning. The percentage of the class average is $90.87 \%$. From the learning results obtained can be described: (1) cognitive aspects, the success of students from cognitive aspects during the learning process with an average percentage of $88.88 \%$ with good categories (B); (2) Affective aspects, the success of students from the affective aspects of this meeting with an average percentage of $91.66 \%$ with the category Very Good (A); (3) Psychomotor aspects, the success of students from psychomotor aspects with an average percentage of $92.08 \%$ with the category Very Good (A). 


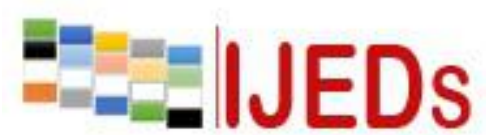

http://ijeds.ppj.unp.ac.id/index.php/IJEDS
International Journal of Educational Dynamics

Vol. 1 No. 1 (pp. 169-174) December 2018

p_ISSN 2655-4852

e_ISSN 2655-5093

\section{Second Cycle of Meeting II}

The results of observations made on the teacher's actions, the score obtained was 59 of the maximum score of 60 with a percentage of $98.33 \%$ with a very good category (A). While for students' actions, the score obtained is 60 from a maximum score of 60 with a percentage of $100 \%$ with a very good category (A). Student learning outcomes seen from the results of evaluations conducted at the end. Based on the results of the study obtained an overview of 32 students, as a whole has achieved mastery learning. This is evidenced by the class average obtained is 95.58 with a percentage of 100\% learning completeness. From the learning outcomes obtained can be described: (1) cognitive aspects, the success of students from cognitive aspects seen during the learning process takes place with an average percentage of $98.95 \%$ very good category (A); (2) Affective aspects, The success of students from the affective aspects of this meeting is $93.53 \%$ with good sagat categories (A); (3) Psychomotor aspects, the success of students from psychomotor aspects is $94.58 \%$ with very good category (A).

\section{CONCLUSION}

From the exposure to the research data conclusions that can be taken are as follows: 1) The implementation of learning with Problem based learning (PBL) strategies, involves assessing the aspects of the teacher and student aspects. Recapitulation of the results of the second aspect of teacher assessment is higher than the recapitulation of assessment results. Teacher cycle I activity which is $80.00 \%$ increased to $94.17 \%$ or increased by around $14.17 \%$ and the recapitulation of the results of the process assessment in the first cycle had also increased in the second cycle with the acquisition of SB (Very Good). While the assessment of student activity, the recapitulation of the results of the assessment of aspects of the second cycle students is higher when compared with the recapitulation of the results of the assessment aspects of students in the first cycle, namely $82.50 \%$ increased to $97.50 \%$ or increased by around $15.00 \%$ and the recapitulation of assessment results increased where students have obtained many SB (Very Good) scores. 3) Application of Problem Based Learning (PBL) learning strategies in science learning in the fifth grade of SDN 10 Sapiran, can improve student learning outcomes. This can be seen from the recapitulation of student 


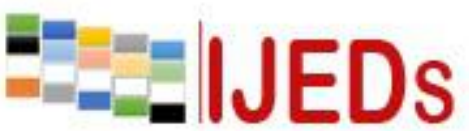

http://ijeds.ppj.unp.ac.id/index.php/IJEDS

\section{International Journal of Educational Dynamics}

Vol. 1 No. 1 (pp. 169-174) December 2018

p_ISSN 2655-4852

e ISSN 2655-5093

learning outcomes in cycle II is higher when compared with the recapitulation of student learning outcomes in the first cycle, which is $78.01 \%$, increased to $93.22 \%$ or increased by around $12.82 \%$. and the recapitulation of the results of the process assessment in the first cycle has also increased in the second cycle where students have obtained many SB (Very Good) scores. Based on the results of the research obtained, it is recommended that: 1) In implementing learning the teacher should also adjust it to the implementation of the steps of the Problem Based Learning (PBL) strategy that is understood. 2) Strategy. Teacher's Problem Based Learning (PBL) can be considered as an alternative science learning strategy that can improve student learning outcomes, because learning with Strategic Problem Based Learning (PBL) will make it easier for students to think critically in solving any problems faced by students for the future, then also be able to think about the material being studied, exchange opinions with other students, and share information that can add insight to students.

\section{REFERENCES}

Amir, T. 2009. Inovasi Pendidikan Melalui Problem Based Learning. Jakarta: Kencana Predana Media Group.

Arikunto, S. 2009. Penelitian Tindakan Kelas. Jakarta: Bumi Aksara

Wena, M. 2010. Strategi Pembelajaran Inovatif Kontemporer Suatu TinjauanKonseptual Operasional. Jakarta: Bumi Aksara

Sudjana, N. 2010. Penilaian Hasil Proses Belajar Mengajar.Bandung : PT Remaja Rosyada

Basrowi and Suwandi. 2008. Memahami Penelitian Kualitatif. Jakarta: Rineka Cipta

Dimyati and Mudjiono. 2009. Belajar dan Pembelajaran. Jakarta:Rineka Cipta

Depdiknas. 2006. Kurikulum Tingkat Satuan Pendidikan Jenjang Pendidikan Dasar. Jakarta: BNSP

Kunandar. 2010. Guru Profesional Implementasi Kurikulum Tingkat Satuan Pendidikan(KTSP) dan Sukses dalam Sertifikasi Guru. Jakarta: Raja Grafindo Persada

Martono, N. 2011. Metode Penelitian Kuantitatif Analisis Isi dan Analisis Data Sekunder . Jakarta: PT RajaGrafindo Persada

Purwanto, M. N. 2006. Prinsip-Prinsip dan Teknik Evaluasi Pengajaran. Bandung: PT Remaja Rosdakarya

Chen, N.-C and Chen, N. C. 2008. An Educational Approach To Problem-Based Learning Introduction To Pbl Teaching Methods. Kaohsiung J Med Sci March Kaohsiung J Med Sci Kaohsiung J Med Sci March, 2424(3), 23-30. 
Demirel, M and Caymaz, B. 2015. Prospective Science and Primary School Teachers Self-efficacy Beliefs in Scientific Literacy. Procedia - Social and Behavioral Sciences, 191, 1903-1908. https://doi.org/10.1016/j.sbspro.2015.04.500

Gorghiu, G., Drăghicescu, L. M., Cristea, S., Petrescu, A.-M., and Gorghiu, L. M. 2015. Problem-based Learning - An Efficient Learning Strategy in the Science Lessons Context. Procedia - Social and Behavioral Sciences, 191, 1865-1870. https://doi.org/10.1016/j.sbspro.2015.04.570

Harun, N. F., Yusof, K. M., Jamaludin, M. Z., and Hassan, S. A. H. S. 2012. Motivation in Problem-Based Learning Implementation. Procedia - Social and Behavioral Sciences, 56 (Ictlhe), 233-242. https://doi.org/10.1016/j.sbspro.2012.09.650

Mat, S., Mohd.Yassin, R., Ishak, N., Mohammad, N., and Pandaragan, S. L. 2012. Model of Problem-based Learning using Systems Approach. Procedia - Social and Behavioral Sciences, 60, 541-545. https://doi.org/10.1016/ j.sbspro.2012.09.420

Moutinho, S., Torres, J., Fernandes, I., and Vasconcelos, C. 2015. Problem-Based Learning And Nature of Science: A Study With Science Teachers. Procedia Social and Behavioral Sciences, 191, 1871-1875. https://doi.org/10.1016/ j.sbspro.2015.04.324

Panlumlers, K., and Wannapiroon, P. 2015. Design of Cooperative Problem-based Learning Activities to Enhance Cooperation Skill in Online Environment. Procedia - Social and Behavioral Sciences, 174, 2184-2190. https://doi.org/10.1016/j.sbspro.2015.02.019

Phungsuk, R., Viriyavejakul, C., and Ratanaolarn, T. 2017. Development of a problem-based learning model via a virtual learning environment. Kasetsart Journal of Social Sciences, 38(3), 297-306. https://doi.org/10.1016/ j.kjss.2017.01.001

Yusof, K. M., Hassan, S. A. H. S., Jamaludin, M. Z., and Harun, N. F. 2012. Cooperative Problem-based Learning (CPBL): Framework for Integrating Cooperative Learning and Problem-based Learning. Procedia - Social and Behavioral Sciences, 56(Ictlhe), 223-232. https://doi.org/10.1016/ j.sbspro.2012.09.649 